\title{
IMPLEMENTASI KEY PERFORMANCE INDICATOR PADA STAFF GROUND HANDLING (PETUGAS PASASI) DI BANDAR UDARA
}

\author{
${ }^{1}$ Sapriyanti \\ ${ }^{1}$ Bank Negara Indonesia, Jakarta, Indonesia, \\ e-mail: sapriyanti.85@gmail.com
}

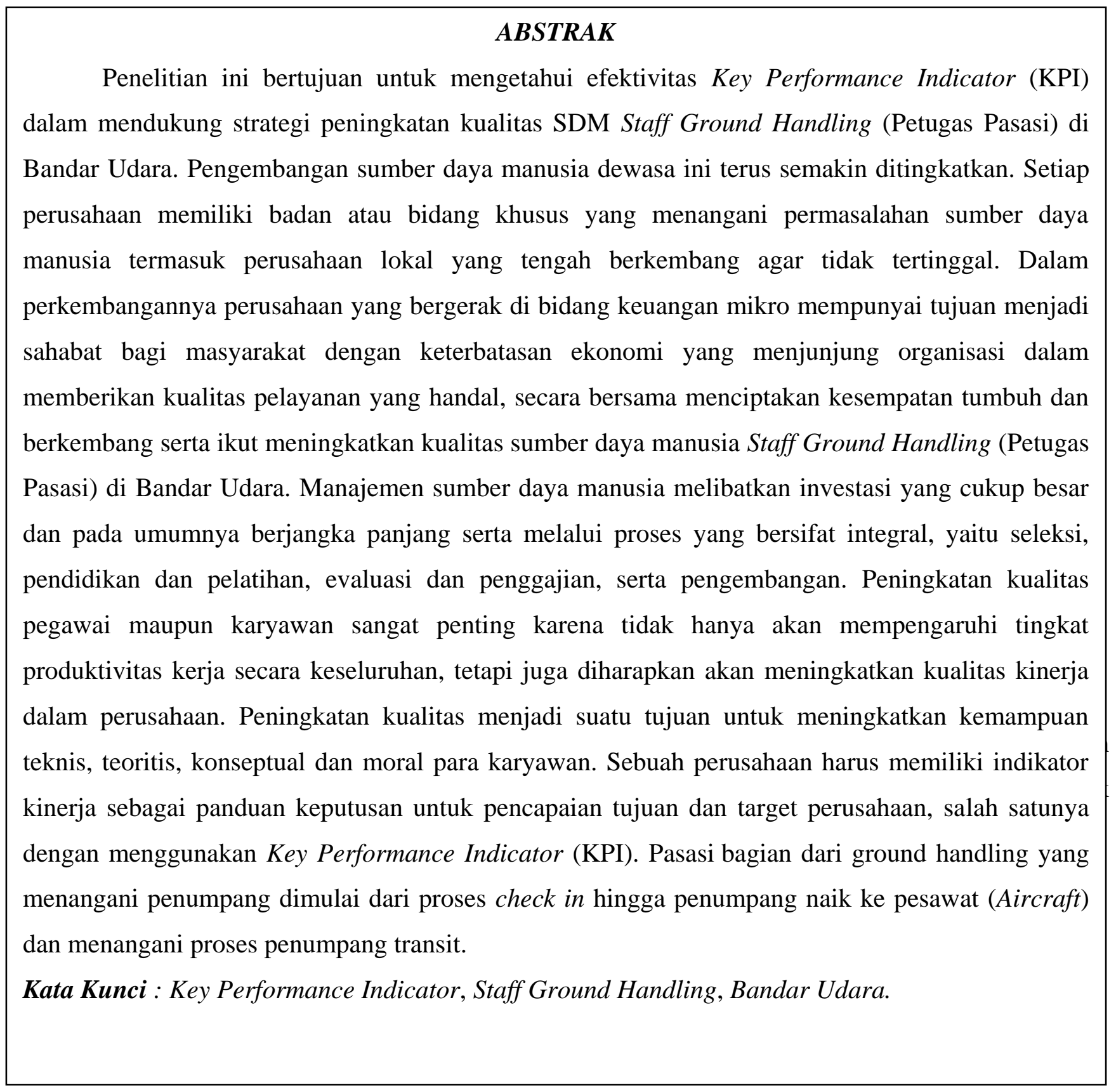




\section{PENDAHULUAN}

Semakin berkembangnya industri pariwisata di Indonesia, berdampaknya pada semakin pentingnya peranan industri jasa pariwisata. Dewasa ini masyarakat lebih suka menggunakan transportasi udara dibandingkan dengan moda transportasi lainnya. Dengan menggunakan transportasi udara udara jarak jauh pun dapat ditempuh dengan waktu yang relatif singkat. Di dalam kegiatan transportasi udara, terdapat jasa pelayanan Ground Handling merupakan tata cara penanganan pesawat, penumpang, barang, bagasi dan cargo mulai dari pesawat take off hingga lepas landas kembali. Ada beberapa bagian unit kerja di kegiatan ground handling salah satunya ialah unit kerja di bagian terminal side. Di Bagian unit kerja tersebut terdapat petugas yang menangani penumpang ketika berada di area terminal side yang meliputi terminal keberangkatan (departure hall) dan kedatangan (Arrival hall) disebut dengan petugas terdapat beberapa permasalahan yang dihadapi oleh petugas pasasi. Dalam memberikan penanganan kepada special passenger terdapat beberapa hal yang perlu diperhatikan dan menjadi tanggung jawab petugas petugas pasasi. Salah satu tanggung jawab yang perlu perhatikan khusus yaitu masih ada beberapa petugas pasasi yang tidak tanggap dan tidak sesuai prosedur dalam melakukan kegiatan, serta tidak melapornya special passenger kepada petugas pasasi.

Penilaian kinerja bermanfaat baik bagi perusahaan maupun pegawai itu sendiri. Adanya penilaian kerja yang sesuai dengan uraian jabatannya akan membuat perusahaan dapat memberikan reward berupa gaji, bonus, bahkan promosi sesuai dengan kondisi yang sebenarnya bahwa penilaian kinerja mempunyai beberapa manfaat, yaitu untuk penerapan sistem reward dan punishment, memberikan umpan balik bagi karyawan untuk pengembangan karier, identifikasi kebutuhan pelatihan pengembangan bagi karyawan, dan mendiagnosa masalah dalam organisasi. Kualitas sumber daya manusia merupakan masalah yang perlu mendapatkan perhatian perusahaan karena kualitas SDM mampu meningkatkan peran serta karyawan terhadap organisasi. Manajemen harus selalu mencari, mengembangkan dan mempertahankan SDM yang sesuai kebutuhan dalam meningkatkan kinerja SDM. Dalam mengembangkan SDM perusahaan membutuhkan tolok ukur sebagai sarana untuk mencapai SDM yang berkualitas. Salah satu sarana yang dapat digunakan adalah Key Performance ini dapat digunakan sebagai acuan karyawan dalam mencapai sasaran kerjanya serta dapat digunakan untuk mengukur seberapa besar pencapaian sasaran kerja yang sudah 
berhasil diselesaikan oleh karyawan. Key Performance Indicator adalah alat ukur yang menggambarkan efektivitas perusahaan dalam mencapai tujuan bisnisnya. Perusahaan menggunakan Key Performance Indicator untuk mengukur kesuksesan pencapaian target mereka. Adapun beberapa karakteristik dari Key Performance Indicator yaitu : Ukuran Non Financial, Ukuran yang sering digunakan (regular measurements), Ukuran yang diketahui oleh manajemen, Semua orang yang ada di dalam suatu organisasi telah mengerti dan memahami Key Performance Indicator, Tanggung jawab kepada individu dan tim, Memiliki efek yang sangat signifikan, Memiliki efek yang positif, Key Performance Indicator diukur dalam periode harian, mingguan dan bulanan. Key Performance Indicator yang baik merupakan suatu hal yang penting dan terus menerus mendapat perhatian dari manajemen. Ketika seseorang menyimpang dari kpi. Pihak manajemen dapat mengambil suatu keputusan dan memanggil orang yang bertanggung jawab tersebut.

Kinerja diukur untuk mengetahui sejauh mana tujuan direalisasikan sehingga manajemen bisa bertindak cepat untuk mengambil keputusan. Manfaat pengukuran kinerja dapat dirasakan secara jangka panjang karena lingkaran bisnis berubah secara dinamis. Dengan mengetahui hasil pengukuran kinerja, simpul-simpul penyebab rendahnya kinerja dapat diketahui sehingga bisa segera diperbaiki, baik karena kelambatan maupun penyimpangan yang terjadi. Ukuran kinerja tercermin dalam Key Performance Indicator merupakan alat bantu atau instrument manajemen agar suatu kegiatan atau proses dapat diikuti, dikendalikan (bila menyimpang, dapat dikenali untuk dikoreksi), dan dipastikan untuk mewujudkan kinerja yang dikehendaki. Salah satu cara agar mencapai indikator yang baik dalam penilaian kinerja karyawan dengan menggunakan metode Key Performance Indicator dengan membandingkan apa yang telah dibuat dengan apa yang telah ditetapkan. Implementasi yang berhasil akan tergantung pada pelaksanaan strategi pemeliharaan yang baik sesuai dengan apa yang telah ditetapkan

\section{LANDASAN TEORI}

Key Performance Indicator (KPI), Menurut Parmenter (2014), key performance indicator adalah sebagai sekumpulan pengukuran yang diciptakan terfokus kepada aspek kinerja organisasi yang paling kritikal untuk kesuksesan organisasi pada kondisi sekarang dan di masa datang. Menurut Warren (2011), key performance indicator merupakan sebuah pengukuran yang menilai bagaimana sebuah organisasi mengeksekusi visi strategisnya. Visi strategis yang dimaksud merujuk kepada bagaimana strategi organisasi 
secara interaktif terintegrasi dalam strategi organisasi secara menyeluruh. Scoring system dengan menggunakan metode Higher is Better, Lower is Better, Must be Zero, dan Must be One, hal tersebut dilakukan untuk mengetahui nilai pencapaian terhadap target masingmasing key performance indicator (KPI), sehingga dapat dilakukan identifikasi perlunya suatu perbaikan. Perhitungan skor pencapaian kinerja masingmasing KPI dihasilkan dengan ketentuan bila indikator kerja menunjukkan penilaian (Efendi dan Hanoum, 2011). Menurut Simamora (2009), Key Performance Indicator (KPI) adalah ukuran yang bersifat kuantitatif dan bertahap bagi perusahaan serta memiliki berbagai perspektif dan berbasiskan data konkret, dan menjadi titik awal penentuan tujuan dan penyusunan strategi organisasi.

Key Performance Indicator (KPI) atau Indikator Kinerja Utama adalah serangkaian indikator kunci yang bersifat terukur dan memberikan informasi sejauh mana sasaran strategis yang dibebankan kepada suatu organisasi sudah berhasil dicapai. Unsur-unsur yang terdapat dalam KPI terdiri atas tujuan strategis, indikator kunci yang relevan dengan sasaran strategis tersebut, sasaran yang menjadi tolak ukur dan kerangka waktu atau periode berlakunya KPI tersebut (Soemohadiwidjojo, 2015). Menurut Rivai (2008), Key Performance Indicator (KPI) merupakan sebuah pengukuran yang menilai bagaimana sebuah organisasi mengeksekusi visi strategisnya. Visi strategis yang dimaksud merujuk kepada bagaimana strategi organisasi secara interaktif terintegrasi dalam strategi organisasi secara menyeluruh.

Menurut Pallan (2007), mendefinisikan Key Performance Indicator (KPI) sebagai yang paling kritikal untuk kesuksesan organisasi pada kondisi sekarang dan di masa datang. Menurut Donelly (2016), Key Performance Indicator (KPI) adalah ukuran berskala dan kuantitatif yang digunakan untuk mengevaluasi kinerja organisasi dalam tujuan mencapai target organisasi. KPI juga digunakan untuk menentukan objektif yang terukur, melihat tren, dan mendukung pengambilan keputusan.

Rivai dan Basri (2005) mengungkapkan bahwa penilaian kinerja yang baik harus memenuhi beberapa syarat seperti berikut: 1 . Reliability, yaitu faktor penilaian harus dapat dipercaya. Ukuran kinerja harus konsisten, jika dua penilai mengevaluasi pekerja yang sama mereka perlu menyimpulkan hal serupa menyangkut hasil mutu pekerja. 2. Relevance, yaitu ada kesesuaian antara penilaian dengan tujuan sistem penilaian, ukuran kinerja harus dihubungkan dengan output riil dari kegiatan yang secara logika itu mungkin. 3. Sensitivity, yaitu beberapa ukuran harus mampu mencerminkan perbedaan antara penampilan tingkat tinggi dan rendah. Penampilan tersebut 
harus dapat membedakan dengan teliti tentang perbedaan kinerja. 4. Practicality, mudah dipahami dan dapat diterapkan secara praktis dan kekurangan data tidak telalu mengganggu.

Menurut Effendi (2007) Dalam mengimplementasikan KPI Terdapat suatu metode untuk merencanakan suatu tujuan yang menggabungkan beberapa kriteria yang disebut SMART (Specific, Measurable, Achievable, Realistic dan Time Sensitive).

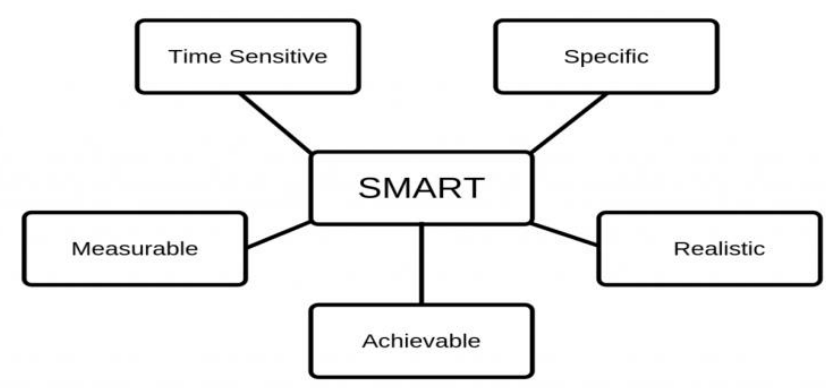

Gambar 1. SMART

- Specific - Tujuan / hasil haruslah jelas dan spesifik, tujuan / hasil yang melebar sangat tidak diharapkan. Ketika tujuan / hasil jelas dan spesifik, sangat mudah diketahui kapan tujuan / hasil tersebut telah dicapai.

- Measurable - Tujuan / hasil harus dapat diukur, baik itu secara kualitas atau pun kuantitas. Hal ini dapat ditempatkan dalam hubungannya dengan performa standar atau harapan dari suatu performa.
- Achievable - Dapat dicapai, tetapi harus diformulasikan sebagai suatu tantangan dan dengan demikian akan menginspirasi organisasi untuk mencapai hasil / tujuan.

- Realistic - menciptakan suatu ide yang merupakan hasil / tujuan haruslah tercapai, tetapi harus juga realistis dan berorientasi hasil.

- Time Sensitive - setiap hasil / tujuan memiliki batasan waktu kapan tujuan / hasil tersebut dapat dicapai. Fakta bahwa tujuan / hasil merupakan sesuatu yang membutuhkan batasan waktu akan membuat suatu kemudahan dalam mengukur suatu peningkatan suatu tujuan/hasil berikutnya.

\section{METODE PENELITIAN}

Metode penelitian yang digunakan adalah metode penelitian kualitatif melalui studi literatur, kajian pustaka dari sudut pandang produktivitas SDM dan menganalisa suatu kinerja petugas pasasi yang melayani customer pada Bandar Udara, Dalam studi tersebut akan jabarkan tingkat eksplanasi Implementasi Key Performance Indicator Pada Staff Ground Handling (Petugas Pasasi) Di Bandar Udara.

Analisis data yang digunakan dalam penelitian ini merupakan analisa deskriptif, Penelitian deskriptif bertujuan untuk 
memberikan gambaran dalam bentuk deskripsi berupa kata-kata mengenai subjek penelitian dari pengamatan terhadap suatu permasalahan. Hasil penelitian tersebut kemudian dianalisis untuk menemukan identifikasi Key Performance Indicator (KPI) yang ada pada perusahaan.Faktor-faktor Key Performance Indicator (KPI) yang sudah didapatkan dan dipahami tersebut dapat dijadikan dasar untuk informasi mengenai efektivitas Key Performance Indicator (KPI).

\section{PEMBAHASAN}

Dalam dunia penerbangan, pasasi bisa juga diartikan sebagai ground handling. Ground handling ini merupakan karyawan yang bekerja di bandara. Tugasnya adalah melayani pembelian tiket, mencetak boarding pass, absensi dalam ruang tunggu, mengatur bagasi, mengatur dan menangani prosedur yang harus dilakukan baik sebelum maupun sesudah penerbangan, serta menangani ketika terjadi delay atau keterlambatan penerbangan. Profesi atau jenis pekerjaan ini merupakan pekerjaan yang pasti dan harus dimiliki oleh setiap perusahaan penerbangan. Bisa juga dikatakan jika ground handling ini adalah front liner dari setiap perusahaan penerbangan.

Seperti yang disebutkan sebelumnya, setiap perusahaan penerbangan pasti memiliki petugas ground handling yang ditempatkan pada beberapa departemen dengan bidang masing-masing. untuk mengenal profesi atau pekerjaan pasasi ini, berikut beberapa departemen yang ditangani beserta tugasnya :

1. Ticketing Staff - Departemen ticketing merupakan petugas ground handling yang bertugas untuk menangani segala hal yang berkaitan dengan tiket konsumen. Tugasnya membantu penumpang dalam pembelian tiket atau pengembalian jika memang dibutuhkan.

2. Check-in Counter - Selanjutnya adalah departemen checking counter yang mana merupakan petugas ground handling yang tugasnya menangani penumpang yang akan melapor untuk melakukan penerbangan. Petugas checkin counter inilah yang akan mencetak boarding pass sekaligus memberikan label pada bagasi penumpang kemudian memasukkannya.

3. Boarding Gate Staff - Petugas ini merupakan bagian dari ground handling yang bertugas di boarding gate. Tugasnya, mendata penumpang yang akan terbang atau akan masuk ke pesawat.

4. Transfer Desk - Departemen berikutnya bernama transfer desk. Petugas dari departemen ini bertanggung jawab untuk menangani penumpang ataupun barangnya yang akan melakukan transit atau perjalanan lanjutan. 
5. Services - Departemen berikutnya yang ditangani oleh pasasi adalah services. Petugas yang bertanggung jawab disini harus memberikan pelayanan ekstra terhadap penumpang-penumpang khusus. Penumpang yang dikategorikan khusus ini adalah penumpang yang menggunakan kursi roda atau anak-anak yang terbang tanpa mendapatkan pendampingan.

6. Lost and Found - Petugas ground handling ini bertempat di terminal kedatangan. Tugasnya menerima laporan dari penumpang yang mengalami kehilangan bagasi atau bagasi tertukar. Petugas lost and found ini akan standby sebelum exit gate dan akan mengecek apakah bagtag yang terdapat di barang bawaan sama dengan bagtag yang dimiliki penumpang. Bagtag ini diberikan oleh petugas check-in ketika memasukkan bagasi.

7. Customer Relation Officer - Terakhir adalah petugas pasasi yang menangani masalah penumpang berkaitan dengan penerbangannya. Petugas ini jugalah yang bertugas menangani penumpang dengan status CIP, VIP hingga VVIP.

Tugas seorang Ground Handling seperti yang sudah saya jelaskan di atas adalah memaastikan semua kegiatan sebuah penerbangan dari Pesawat Takeoff hingga landing kemudian Takeoff Lagi Lancar, Ground Handling Memiliki tanggung jawab terhadap semua kelancaran itu. Maskapai telah memberikan tugas kepada Perusahaan Ground Handling untuk memastikan semua kegiatan penerbangan berjalan dengan lancar.

Hasil penelitian menunjukkan bahwa penilaian kinerja berbasis kompetensi dan KPI yang telah disusun: 1. Dinilai lebih reliabel dan relevan karena lebih konsisten serta aspek yang dinilai lebih dapat diamati karena sesuai dengan job description, terlebih KPI bisa dimonitoring secara priodik. Ukuran dan standar lebih jelas, spesifik dan terukur. Penilaian kinerja ini juga dinilai lebih sensitif karena mampu membedakan karyawan dengan kinerja tinggi maupun rendah berdasarkan nilai yang diperoleh. 2. Prosedur penilaian juga direspon dengan baik karena melibatkan karyawan yang dinilai, dan rekan kerja bukan hanya atasan langsung sehingga penilaian kinerja ini dinilai lebih obyektif. 3. Dapat digunakan sebagai dasar pengambilan keputusan yang berkaitan dengan pengembangan SDM. 4. Kelemahan dari penilaian kinerja ini adalah metode multireter yang dianggap kurang praktis karena harus melalui proses rekapitulasi dan memerlukan waktu yang lebih lama daripada penilaian satu rater. Proses monitoring KPI membuat pekerjaan karyawan jadi bertambah karena perlu 
pencatatan rutin tiap harinya. Meskipun demikian pihak manajemen memberikan respon positif.

\section{KESIMPULAN}

Key Performance Indicator harus dipilih secara cermat untuk mencerminkan indikator kinerja yang penting bagi organisasi sesuai dengan strategi perusahaan dan faktor kunci kesuksesan organisasi. Penetapan Key Performance Indicator dan sasaran yang akan dicapai tidak dapat dilakukan secara asal-asalan, tetapi harus dipilih dan ditentukan menggunakan metode yang tepat dan sistematis. Memilih Key Performance Indicator dan menetapkan sasaran Key Performance Indicator secara tepat akan dapat mengarahkan organisasi pada identifikasi potensi perbaikan atau peningkatan kinerja sehingga Key Performance Indicator sering sekali diasosiasikan dengan inisiatif yang terkait peningkatan kinerja Sebagai salah satu perangkat utama manajemen organisasi, tujuan utama dari penetapan Key Performance Indicator tersebut adalah: 1. Untuk menghubungkan antara visi-misi-tata nilai, strategi organisasi, dan sasaran kinerja organisasi dengan aktifitas organisasi untuk mencapai sasaran kinerja yang diinginkan. 2. Untuk mengukur tren kinerja organisasi dan/atau divisi apakah terdapat kenaikan atau terjadi penurunan yang signifikan. 3. Untuk membandingkan kinerja organisasi terkini dengan kinerja historis organisasi, atau membandingkan dengan kinerja organisasi lainnya sehingga organisasi medapatkan gambaran mengenai keunggulan atau kelemahan organisasi dibandingkan pesaing, serta mengetahui peluang-peluang untuk menciptakan nilai tambah. 4. Key Performance Indicator organisasi digunakan sebagai dasar penetapan Key Performance Indicator atau sasaran kerja divisi dan individu. 5. Hasil pencapaian Key Performance Indicator menjadi dasar untuk memberikan penghargaan dan konsekuensi sehingga Key Performance Indicator juga bermanfaat untuk mendorong motivasi bekerja dan perilaku yang baik dari karyawan.

\section{DAFTAR PUSTAKA}

Donelly. (2016). Produktivitas Kerja. Edisi Kedelapan. Birarupa Aksara, Jakarta.

Effendy. (2007). Humas Suatu Studi Komunikologis. PT.Remaja Rosida, Bandung.

Mahsun. (2011). Pengukuran Kinerja Sektor Publik, BPFE, Yogyakarta.

Palan. (2007). Competency Management. PPM Indonesia, Jakarta.

Parmenter. (2007). Key Performance Indikators, PT Elex Media Komputindo, Jakarta. 
Rivai, (2008). Manajemen Sumber Daya

Manusia untuk Perusahaan. PT.Raja

Grafindo Persada, Jakarta.

Rivai, V dan Basri, M. F. A. (2005).

Performance Appraisal. PT. Raja

Grafindo Persada, Jakarta.

Simamora, (2009). Manajemen Sumber Daya Manusia, Gramedia, Jakarta.

Warren, 2011. Key performance indicators (KPI) - definition and action: Integrating KPIs into your company's strategy. London: ATI. 